Journal

of Geography,

Politics and Society

(x)

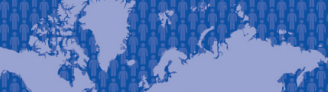

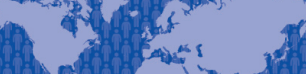

at

is

.

4)

$7(4) / 2017$

\section{Journal of Geography, Politics and Society}

$2017,7(4), 32-40$

DOI 10.4467/24512249JG.17.035.7635

\title{
TYPOLOGY OF RUSSIAN REGIONS BY LEVEL OF SUBURBAN RAILWAY TRANSPORT: DEVELOPMENT AND AREAL ASPECTS OF MANAGEMENT
}

\author{
Kirill Samburov \\ Institute of Earth Sciences, St. Petersburg State University, 10th line of the Vasilivsky Island, 33-35, 199004 St. Petersburg, Russia, \\ e-mail: blok04@gmail.com
}

\section{Citation}

Samburov K., 2017, Typology of Russian regions by level of suburban railway transport: development and areal aspects of management, Journal of Geography, Politics and Society, 7(4), 32-40.

\begin{abstract}
The post-reform period of development of the railway passenger complex was marked by a significant number of crises that led to aggravation of the transport situation in a number of Russian Federation entities. This article is devoted to the problems of regional analysis of the level of suburban service development; it outlines the main trends in management of the local railway transport. The main development indicators have been identified; the grading of Russian regions in these terms has been traced; two key models of regional policy in the sphere of railway suburban service to the population have been defined.
\end{abstract}

\section{Key words}

suburban train, Russian railway service, passenger service, regional policy, typology of Russian regions, transport geography.

Received: 03 October 2017 Accepted: 10 November 2017 Published: 29 December 2017

\section{Introduction}

Transport is an integral part of life in any territory; it engenders links that consolidate the region. At the same time, the actual functioning of a unified regional transport system depends not only on the areal features of the region, but also on the decisions of authorities of a Russian Federation entity. They develop a concept for functioning of this complex in all its aspects. The inherent task is to provide the population with passenger traffic service in the region.

In the present-day Russia, the organization of passenger transportation process within a regional transport system through the local (suburban) and long-distance traffic is one of the functions of the regional authorities. Forming orders for transportation services, entering into contracts with carrier companies, providing necessary documentation, organizing a system for subsidizing unprofitable means of transport - all this falls directly within a spectrum of responsibilities of a Russian Federation entity. Each of them, proceeding from their rights and responsibilities as well as own resources, develops its own strategy for realization of transport policy - provision of the population with transport. Many aspects of life of the population depend precisely on how it is implemented. 
One of the key means of transport in local service in most regions is a suburban train. The current stage of development of the railway passenger complex in the Russian Federation can be correctly called a post-reform period. The railway transport reform has resulted in creation of an entirely new system of forming regional orders for passenger traffic, as well as in change of subsidizing system for commercially unfeasible, though socially important, routes in subsidized regions, where commuter trains often were a single means of public transport, connecting towns and settlements with regional or local centres. This resulted in increased competition between the railway and road transport in the sphere of suburban service.

This reform was by no means painless. Some researchers in particular believe that a return to the original centralized system of passenger traffic would be necessary (Колин, 2015). These ideas originated because of the conflicts in a number of regions, both between regional authorities and carrier companies and between the population and the authorities, which conflicts were a result of serious blunders when setting up subsidiary companies of Russian Railways Joint-Stock Company. It should be noted that the process of setting off the suburban service as a separate business unit involved some contradicting tendencies: on the one hand, preservation of socially oriented suburban routes, and on the other hand, deriving maximum profit. The impossibility of lossless operation of such companies in most of the country's territory is confirmed by the experience of other states; in particular, significant state subsidies are characteristic of Germany, France, Italy and a number of other states (Шнейдер, 2013). A great number of problems revealed in the course of the suburban complex reform resulted in a significant reduction of railway traffic as well as number of routes in several regions of the country.

\section{Key indicators of the level of local passenger service development}

Let us analyze the main characteristics of suburban railway transportation in the present-day Russia. The local railway communication is not always aimed at provision of due commuting service in large-city agglomerations; therefore division into the following types would be feasible (Неретин, 2015):

1. Routes in agglomerations of large cities - they are aimed at servicing the intensive passenger traffic both in intraregional and interregional transportation. This type should include commuter trains in Moscow, St. Petersburg, Novosibirsk and a number of other agglomerations.

2. Suburban routes in medium-size cities - they are aimed at servicing relatively thinly-populated agglomerations. This type should include commuter trains of Khabarovsk region, Kurgan region and a number of other areas.

3. Routes of peripheral territories - they are characterized by insignificant passenger traffic, but the service may not be liquidated due to the absence of alternative means of transport. The Dno - Morino route in Pskov region can be given as an example of such route, where a number of settlements have no other connection with the district centre. Also this type may include the routes between major railway junctions having no in-between big cities, for instance, the route Nevinnomysskaya - Mineralnye Vody in Stavropol region. The following marker indicators are important characteristics for studying the specific features of suburban railway service in the regional context:

- share of suburban service in the overall structure of railway traffic in the region;

- percentage of coverage of suburban passenger companies' losses by regional authorities;

The grading of regions in terms of these indicators was made using the Sturgess formula:

$$
n=1+3,322 \lg N \text {, }
$$

where $n$ is the number of groups; $N$ is the number of aggregate units (number of subjects).

However, the resulting groups were enlarged to reflect the differences more accurately - more fractional division for medium and high values.

On the average, the share of suburban railway service in the Russian Federation is 90.29\% (Регионы России..., 2015), which is a consequence of high proportion of federal-importance cities for this type of rail transportation. It should be noted that the medial index for the regions is $73.41 \%$, which is closer to understanding the actual structure of the railway traffic. 40 of 82 explored Russian Federation entities ${ }^{\bigotimes}$ (Fig. 1) belong to two categories: regions with medium and high share of suburban service. These types include regions with a centre in million-plus cities or regions where the regional centre share is significant, for instance, Primorsky territory. The Russian Federation entities representing these types have a highly developed suburban service, as a rule (exceptions are the Republic of Adygea, the Republic of Karachaevo-Cherkessia and the Jewish Autonomous Region), that is, the regions where suburban routes are predominant in the agglomerations of large cities. The following trend is also noticeable: the higher 


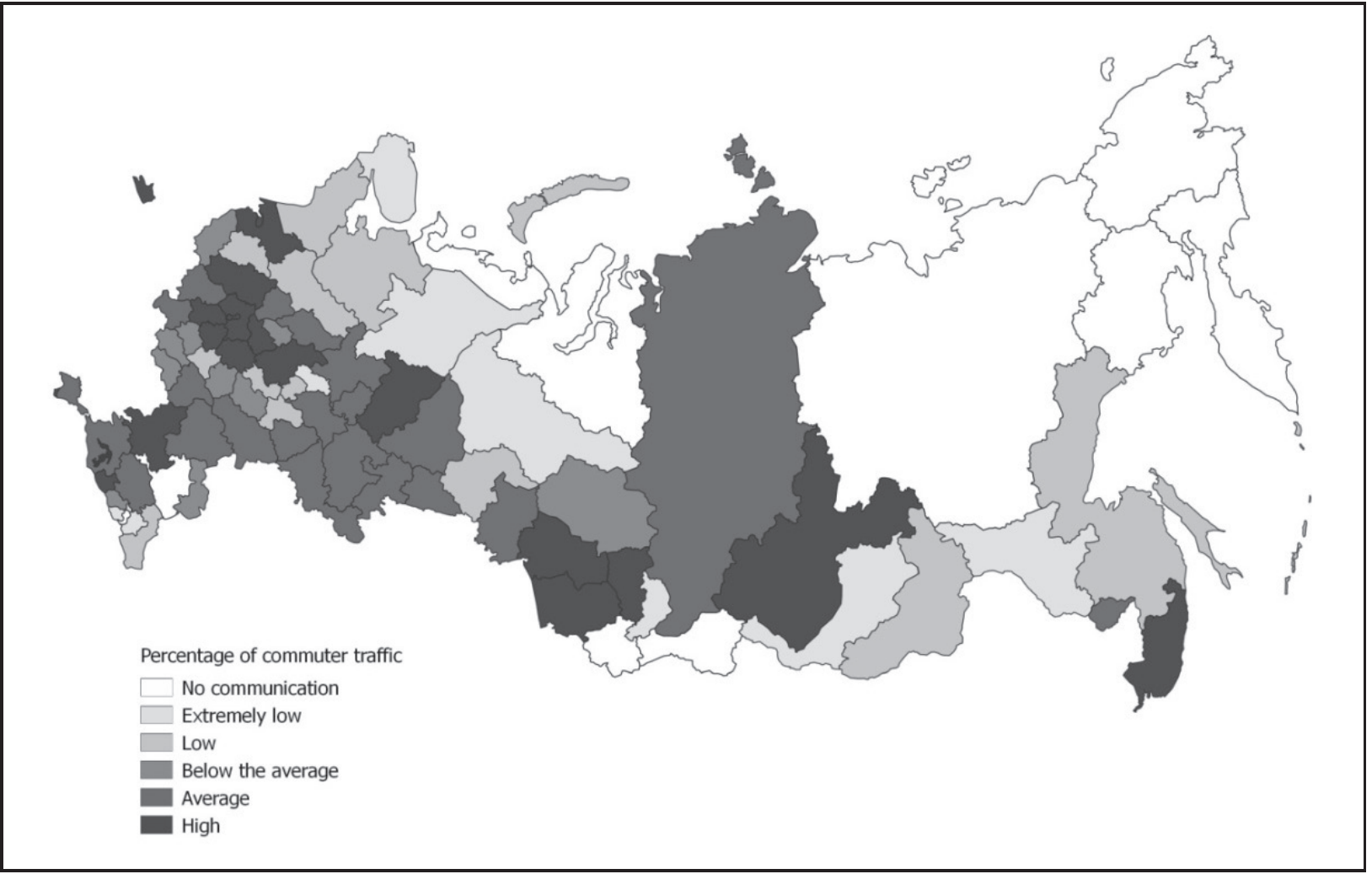

Fig. 1. Types of regions by share of commuter trains in the structure of passenger railway traffic 2014.

Source: Регионы России.., 2015.

the density of railways in the region, the higher the proportion of suburban service.

32 of 82 Russian Federation entities have low shares of suburban service - the regions of three types: with a share below the average; low and extremely low shares. In addition to the above gradation, they are divided into two groups:

1. Regions with underdeveloped suburban complex - this type is characterized by a mismatch in development of communication routes to the scope of suburban service. It includes the following Russian Federation entities: Belgorod region, Ivanovo region, Kursk region, Orel region, Tambov region, Pskov region, the Republic of Kabardino-Balkaria, Penza region, Lipetsk region, Vologda region, Novgorod region, the Republic of Dagestan, the Republic of Mordovia, the Republic of Chuvashia, Ulyanovsk region, the Republic of North Ossetia - Alania, the Chechen Republic, the Republic of Mari El.

2. Regions with highly developed long-distance railway service - this type includes regions with an underdeveloped network of railways and/or a large area; the main passenger transportation in such regions is carried out by long-distance trains - Astrakhan region, Tomsk region, the Republic of Karelia, Arkhangelsk region, Tyumen region, the Republic of Khakassia, Transbaikal region, Khabarovsk region, Sakhalin region, the Republic of Komi, Murmansk region, the Khanty-Mansiysk Autonomous Area, the Republic of Buryatia, Amur region.

There also exist four regions with the absence of suburban railway service and six regions with a total absence of railway transport. One should note, taking the regions with the total absence of suburban service, the Yamal-Nenets Autonomous Area and the Republic of Sakha-Yakutia, that are characterized by a quite well-developed complex of long-distance communication and a small number of settlements located along the railway. The Republic of Ingushetia, on the other hand, is a region where suburban railway service can become the key transport in the future, as the only railroad in the region connects the largest settlements of the republic: Nazran, Karabulak, Sunzha.

The analysis of current trends in development of the suburban railway complex in the Russian Federation entities would be impossible without taking the factor of regional authorities' policy into account - since the regional authorities in the present-day Russia have one of the key tools of management - provision of transport service to the population living in a particular region. As it was already mentioned, the range of their powers includes conclusion of contracts for transport service to the public 
with companies operating in the field of passenger service, and, accordingly, their subsidizing aimed at compensating for shortfall in incomes.

The system of subsidizing suburban railway traffic, functioning in all regions since 2011, has not found support with the Russian Federation entities' authorities. Most of them are incapable or unwilling to fully compensate the shortfall in incomes to suburban passenger companies, which leads to regular conflicts in this sphere between the authorities and the carriers.

Only 11 regions, as of the year 2014, completely subsidize the suburban complex (Щукин, 2015), another four function without loss (Moscow, St. Petersburg, Moscow and Astrakhan regions). This situation shows that we are facing a crisis of this means of railway transportation. It should be noted that it is predominantly the regions with the poorly developed suburban complex (for instance, the Republic of Adygea and the Republic of KarachaevoCherkessia, the Khanty-Mansiysk Autonomous Area, Tomsk and Sakhalin regions) that fully compensate the losses as they are characterized by insignificant losses due to small scope of traffic; this extends as well to the regions with high-intensity and highdemand suburban complex (for instance, Vladimir and Ryazan regions). The first group will also include Astrakhan region which has become loss-free due to the low-intensity suburban traffic; while the second group will include Moscow region, as they are similar in their characteristics to the above-mentioned territories.

Also, 18 regions can be classified as fairly problem-free, being marked by quite full or nearly full compensation policy. This category can be also correctly divided into two groups according to the features of operation of the suburban complex:

1. Regions with low-intensity suburban service, and accordingly, with a low level of suburban companies' losses - the Republic of Mordovia, the Republic of North Ossetia and the Republic of Khakassia; Lipetsk, Murmansk and Orenburg regions.

2. Regions with a relatively developed suburban complex - normally this list includes the regions that are holders of suburban companies' shares (Щукин, 2015) (Krasnodar, Krasnoyarsk and Perm regions; Volgograd, Kemerovo, Novosibirsk, Omsk, Samara and Sverdlovsk regions, the Republic of Tatarstan), the exceptions are the Republic of Bashkortostan and the Republic of Udmurtia.

The most extensive are two groups that include the regions that compensate the lost income to carrier companies incompletely (slightly more than a half) or partially. Each of these groups comprises 14 regions. This category can be characterized as most unbalanced, since the lack of subsidizing can lead to a situation of crisis in the region, which has actually happened to a number of them. It should be noted that the Russian Federation as a whole also falls into this category, which evidences the recessive state of the complex in general within the country. Accordingly, it can also be divided into several types:

1. Relatively prosperous areas - Arkhangelsk, Irkutsk, Kaluga, Nizhny Novgorod, Rostov and Yaroslavl regions, the Republic of Komi, Altai and Primorsky territories, Jewish Autonomous Region. These Russian Federation entities are characterized by preservation of acceptable traffic intensity values, however the lack of subsidizing can lead to negative consequences for the region.

2. Pre-recessionary areas - Amur, Voronezh, Ivanovo, Kaliningrad, Kirov, Kursk, Penza, Saratov, Tambov, Tula and Chelyabinsk regions, the Republic of Kabardino-Balkaria and the Republic of Chuvashia. These regions are characterized by gradual decrease in intensity of traffic, in the number of transported passengers, as well as by significant extent of cancellation of commuter trains. For instance, in 2015 there was a threat of total withdrawal from suburban traffic in Tula region.

3. Recessionary areas - the republics of Dagestan, Karelia, Mari El and Chechnya, Novgorod region. They are primarily characterized by preservation of minimum traffic, as well as by prospects of complete renouncement of suburban traffic; for most republics this will not be critical, while possible cancellation of railway service for Karelia and Novgorod region would lead to significant deterioration of the situation in a number of populated areas.

Among the recessionary regions are 10 areas characterized by a low level of compensation to suburban passenger companies, as well as two regions that have not envisaged the costs of subsidizing the carriers in their budget. These regions are in the most dangerous situation with respect to full-value functioning of the suburban railway complex. It is worth noting that almost all the regions relating to this type have faced the menace of complete or almost complete liquidation of traffic at some point. For instance, in January 2015, Vologda region (Ильин, 2015) was completely denied of suburban service; a similar situation took shape in Pskov region at the same period. Tver region and a number of routes in Leningrad region were under threat of almost complete withdrawal from railway service. Summing up, it can be noted that this factor affects the operation 
of passenger service in the region significantly, so highlighting it as one of the indicators for development of the suburban railway complex is justified.

As already mentioned, a critical situation took shape in the sphere of suburban service at the onset of 2015; it was recorded not only in the above recessionary areas, but also in relatively prosperous regions. In January 2015, termination of service of more than 300 commuter trains in 39 regions of Russia was announced (Власов, Илюхина, 2016). This situation took shape as a result of a conflict between the regional authorities and the carriers because of the Russian Federation entities' debts to the said companies. As far as the routes and regions performing socially important functions were affected in the first place, the conflicts gave rise to a new aspect dissatisfied residents; rallies and picketing, demanding return of commuter trains (including the Republic of Buryatia, the Republic of Karelia, Vologda and Pskov regions and a number of other regions), took place in a number of areas. The greatest activity was recorded in Vologda region where actions of protest were held almost weekly in the period from December 2014 to February 2015.

The protests, court disputes between regional authorities and carrier companies, frequent cancellation of particular commuter trains - all this took place in virtually all constituent entities of the Russian Federation, which makes it possible to compare them in regional aspect. For this purpose, a content analysis of a group "Suburban Train» in the social network «Vkontakte» was undertaken, where the users recorded major conflict events in the sphere of local passenger railway service. A conflict event was understood in this case as an event caused by disagreement between the authorities, carriers and passengers, which resulted in drastic deterioration in transport accessibility in a number of settlements, or was its consequence. The analysis of publications in the group was carried out in the period from January 1, 2013 to March 1, 2016. During that period, 362 conflict events were recorded in 58 Russian Federation entities (Fig. 2).

It should be noted that there exists a negative correlation of Pearson (-0.42) between the amount of compensation provided for by the regional budget and the number of events. In this case, even full compensation in a region (taking even the profitability of the suburban complex) does not exclude possible conflicts in the sphere of local railway service. For instance, in Vladimir region, in spite of full compensation of the shortfall in the carriers' income,

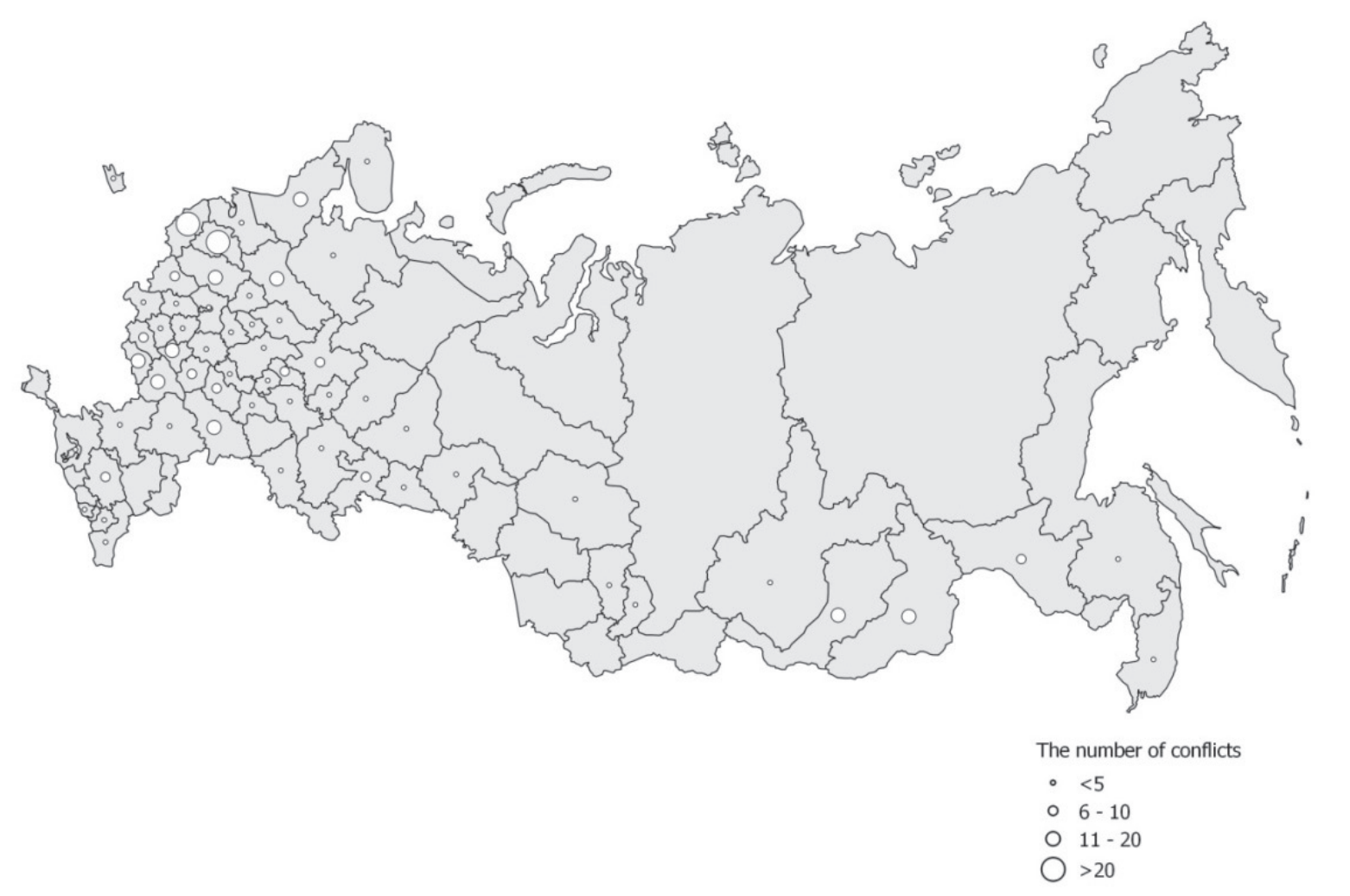

Fig. 2. Number of conflict situations in the Russian Federation entities within the period from January 1, 2013 to March 1,2016

Source: own elaboration. 
12 commuter trains were cancelled simultaneously in January 2015. In the same year, the regional authorities of Kurgan region expressed dissatisfaction in the press regarding the volume of funds specified in the agreement with the carrier company, and in 2014 the passengers were picketing in connection with cancellation of a train Chelyabinsk-Kurgan. However, the greatest number of conflicts arose in the regions where compensation was provided for in the insignificant amount, which aggravated the negative trends in the suburban complex. In Pskov region, where 37 events were recorded, only $21 \%$ of the required amount was compensated in 2014; in Novgorod region -31 events and $47 \%$ respectively, in Vologda region - 20 events, with no compensation from the regional budget.

\section{Typology of the Russian regions by level of development of suburban service}

In order to justify the offered models of operation of suburban passenger service in the regions, and to identify the approximate level of development of this type of transportation (more precise definition is not possible due to inadequate statistics), it is necessary to typify all the regions. It was concluded, proceeding from the results of analysis of the statistical base, that it is most optimal to study the developmental characteristics of the local passenger service on the basis of calculation of development indices using the methodology similar to the human development index. The efficiency of use of this type of indices for passenger traffic was proved in a monograph by C.A. Тархов (2015) devoted to the areal coherence of territories. The book describes the coherence processes within the Russian Federation and measures the transformation of this phenomenon on their basis. Accordingly, it is possible to apply this calculation method for studying other transport characteristics; despite the fact that the development of suburban railway transport in the region is conditioned by many factors, it is still possible to assess its current state by determining the railway suburban service development index (RSSDI):

$$
R S S D I=\left(w+p_{s}+k\right) / 3
$$

where $w=W_{i} / 100 ; p_{s}=P_{s i} / P_{\max } ; k=K_{i} / 100 ; W$ is the share of suburban service in the overall structure of railway traffic; $P_{s}$ is the number of suburban trips per resident of a region; $K$ - the percentage ratio of coverage of suburban passenger companies' losses. According to the received data, a regional typology sketch map was developed (Fig. 3), showing the development of suburban railway service in the regions.

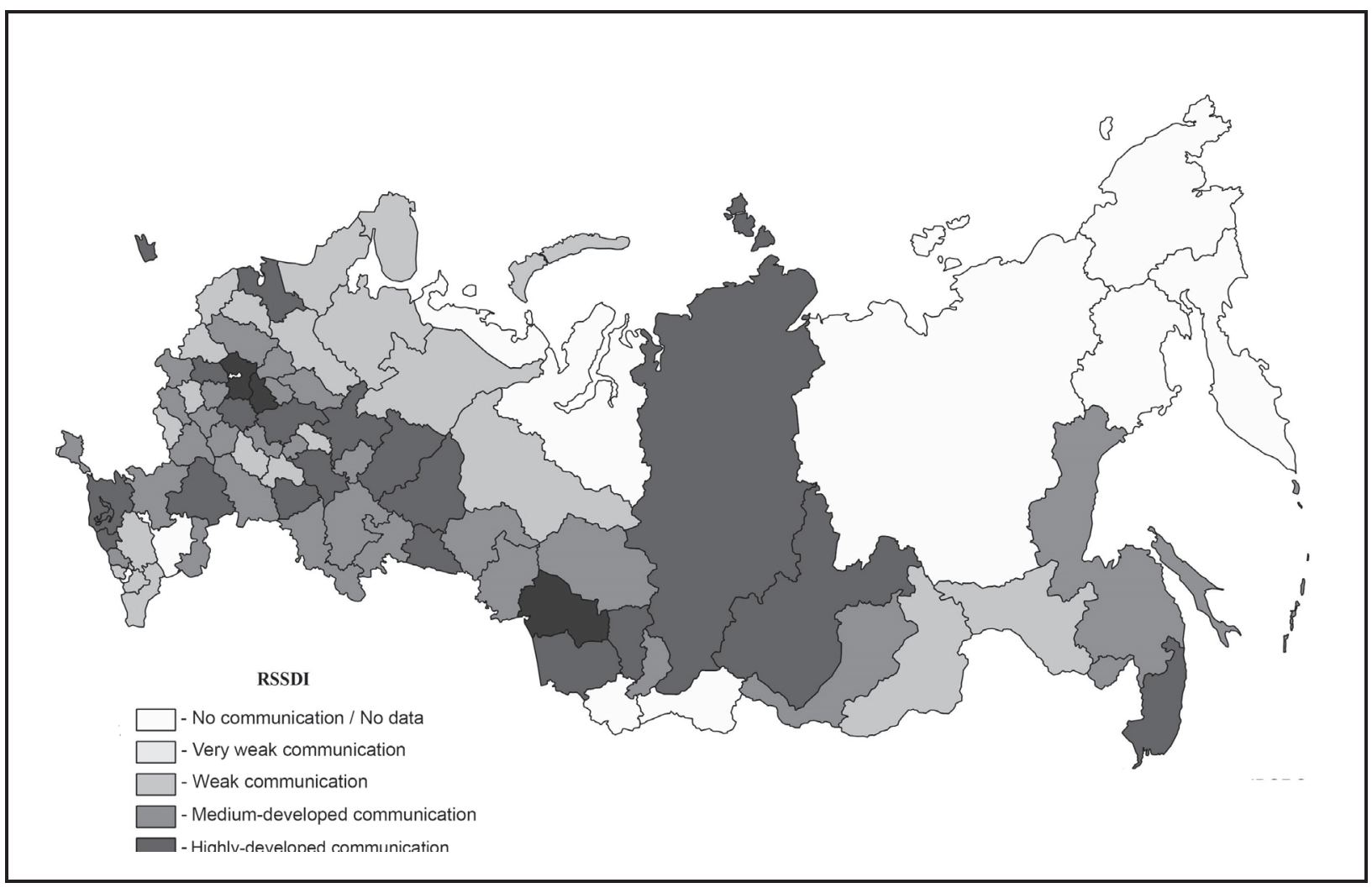

Fig 3. Typology of regions in terms of development of suburban railway service 2014

Source: own elaboration. 
The regions were divided into six types according to the level of development of the above complex:

- Regions without suburban railway service - the Republics of Altai, Kalmykia, Sakha-Yakutia and Tyva; Nenets, Chukotka and Yamalo-Nenets Autonomous Areas, Magadan region and Kamchatka territory.

- Regions with expressly underdeveloped suburban service - RSSDI from 0.001 to 0.200 - no such regions were revealed in the research.

- Regions with underdeveloped suburban service - RSSDI from 0.201 to $0.400 ; 20$ regions of this type were found. They are characterized by low railway passenger traffic, great importance of long-distance railway service, often a low level of compensation for shortfall in income. These regions, as a rule, are recessionary in terms of passenger railway service; the operation of this complex involves a significant number of conflicts between regional authorities and carrier companies. The exceptions within this type are poorly developed large-area regions of the European North and Siberia (the Komi Republic, Arkhangelsk and Murmansk regions, the Khanty-Mansiysk Autonomous Area), where the low index values are conditioned by areal characteristics, not by actions of regional authorities. The most demonstrative example of regions of this type is Vologda region that has the lowest index among the Russian Federation entities; this region, as already mentioned, was barred from suburban service in January 2015 because of a conflict between the regional authorities and the Northern suburban passenger company. An example of another type of conflict was Belgorod region where the authorities repeatedly sued the suburban passenger company "Chernozemie" and the North Caucasian suburban passenger company.

- Regions with a medium-developed suburban service - RSSDI from 0.401 to 0.600 . This type includes 28 regions which are characterized by relatively low rates of traffic; however the operation takes place in the conditions of a harmoniously developed complex that provides the population with its services to a full extent. The group is still not crisis-free, as various conflicts are typical for it as well; for instance, Tula region could lose suburban service in February 2015. But in general it is worth noting that this type is quite stable, and various problems affecting the operation of the suburban service are resolved quickly in a dialogue between the regional authorities and carrier companies.

- Regions with highly developed suburban service - RSSDI from 0.601 to 0.800 . This type includes 20
Russian Federation entities characterized by high figures of transported passengers, full or nearly full subsidization of the suburban passenger companies operating in the region, high share of suburban service in the structure of railway traffic. They include both small-size regions with a relatively developed suburban complex (the republics of Adygeya and Karachaevo-Cherkessia; Kaliningrad, Kaluga and Ryazan regions) and large regions that comprehensively develop the railway service as one of the key means of passenger traffic - Volgograd, Irkutsk, Kirov, Kurgan, Nizhny Novgorod, Samara and Sverdlovsk regions; Krasnoyarsk, Perm and Primorsky territories, the Republic of Tatarstan. Leningrad region should be characterized separately since this region is closely connected with St. Petersburg; it has high figures of passenger traffic. However, the regional authorities did not ratify the costs of subsidizing the suburban complex in the budget, which ended in a winter crisis of 2014-2015, when there was a threat of cancellation of trains in a number of socially significant routes.

- Regions with extremely highly-developed suburban service - RSSDI from 0.801 to 1.000. This type includes only three regions - Vladimir, Moscow and Novosibirsk regions. They are characterized by the highest figures of transported passengers, by profitability or full compensation for losses of suburban passenger companies. The authorities of these regions make the suburban railway service a key element of operation of the passenger service in the region.

This typology, operating with three indicators and a development index based on them, highlights the key features of the current state of the suburban railway complex in the regions. The analysis of these features makes it possible not only to identify the current characteristics of the complex, but also to base the further development of suburban service in the Russian Federation entities upon them.

\section{Directions of regional policy in the sphere of suburban railway traffic}

One may conclude, on the basis on the held analysis, that all the Russian Federation entities having a suburban railway service can be divided into two groups (Fig. 4):

- Regions characterized by a policy of preferential withdrawal from suburban railway service in favour of bus transportation - they are characterized by frequent conflicts, steady decline in orders for transportation. Only those suburban 


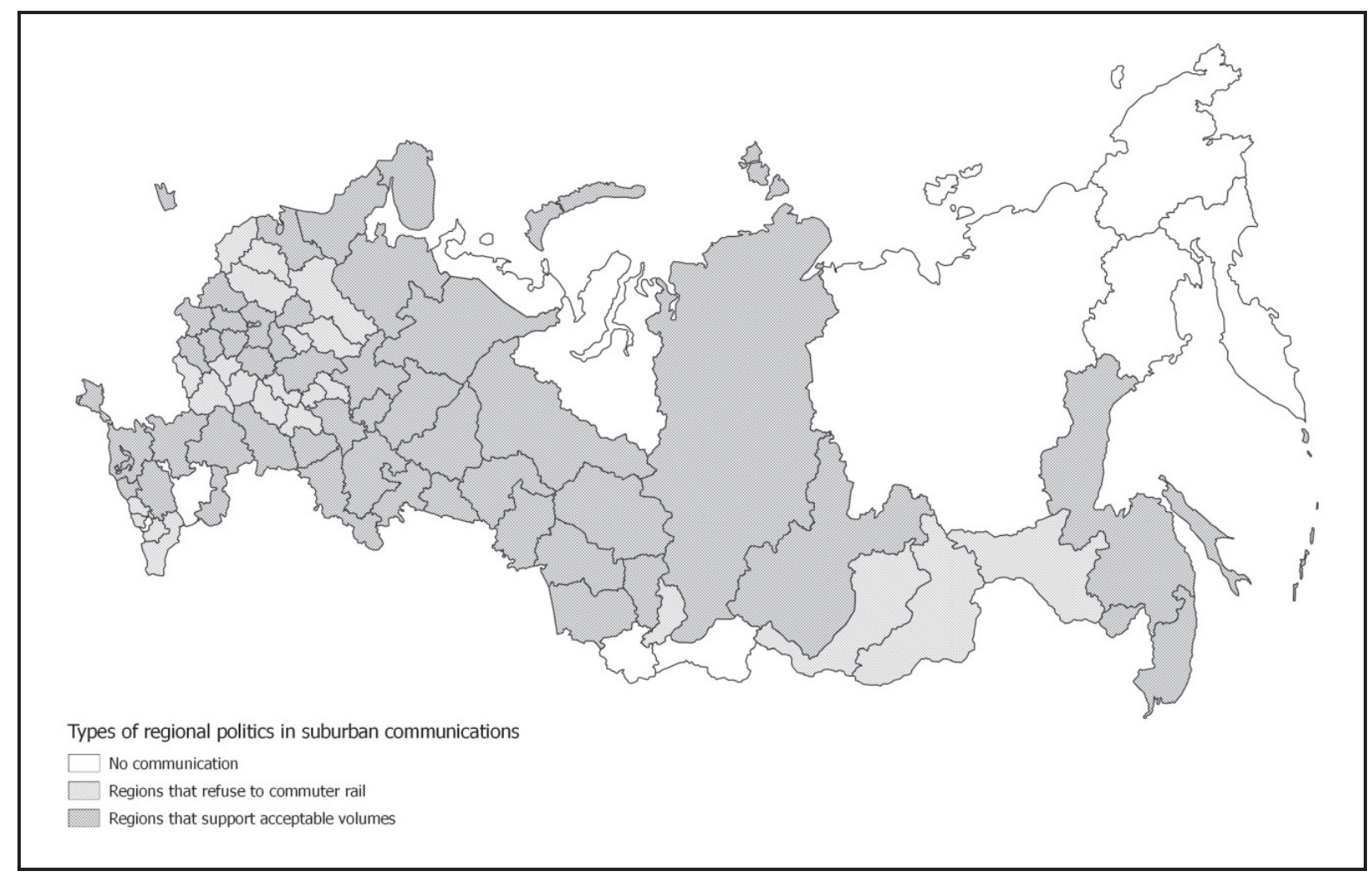

Fig. 4. Types of regional policy in the sphere of suburban railway passenger service 2014

Source: own elaboration.

routes that provide for no alternative means of transport remain.

- Regions characterized by a policy of maintaining acceptable scope of service for full-value functioning of the suburban railway complex - the conflicts in these regions are less frequent; at the same time not only the geography of routes, but also the pairing of trains is predominantly preserved. In some regions, the routes that were previously closed are resumed - in Primorsky territory, Saratov region and in several others.

It should be noted that it is impossible to single out any regions in the Russian Federation preserving the tendency to extend the geography of commuter train routes and/or to increase the frequency in their service in the post-reform period. Some success in the development of this type of railway service was characteristic of Leningrad and Moscow regions (introduction of high-speed trains in a number of routes), Altai territory (increase in traffic frequency on the route Barnaul-Biysk) and a number of others. However, it is worth noting that one can observe shortage of passengers and reduction in traffic volumes even in these regions.

\section{Brief conclusion}

Summarizing the results of the research, it is worth noting that the post-reform period at the suburban railway service was characterized by considerable recessionary phenomena. Since the emergence of a fundamentally different operation scheme for the railway complex in 2011, the preservation of acceptable volume of traffic has become increasingly difficult for regional authorities due to significant losses involved in this type of transport communication. At the same time, the need to preserve socially important routes, along with the expressed temptation to withdraw from commuter trains in favour of bus transportation, entail a significant complication in making decisions regarding development of passenger transport. One should note as well the emerging contradictions between the regional authorities and carrier companies that often lead to development of protest moods among the population. All this encourages the managers to pay more attention to the micro-regional level in order to take into account both the peculiarities of transport systems at the local level and the demands of the population. For more detailed specification of characteristics of the suburban railway complex, it is necessary to study the current trends at the regional level and to make a detailed analysis of every route on their basis. 


\section{References}

Map of Russian regions, https://upload.wikimedia.org/ wikipedia/commons/5/5c/Russia-Subdivisions_with_ Crimea.png [19.09.2017]

Власов А.В., Илюхина С.С., 2016, Развитие российских региональных систем железнодорожных пассажирских сообщений с использованием зарубежного опыта (на примере Österreichischen Bundesbahnen Ag.; Deutsche Bahn Ag.), Модернизация. Инновачии. Развиmue, 1(25), 141-146.

Ильин В.А., 2015, Настораживающие тенденции, Экономические и социальные перемены: факты, тенденции, прогноз, 1(37), 9-15.

Колин А.В., 2015, Актуальность системных преобразований в пригородных железнодорожных перевозках, Транспорт Российской Федерачии. Журнал о науке, практике, экономике, 1(56), 7-11.

Неретин А.С., 2015, Роль местного железнодорожного сообщения В обеспечении мобильности населения малолюдных районов (на примере Костромской области), Региональные исследования, 4(50), 34-42.

Регионы России. Сочиально-экономические показатели 2015 2., 2015, Федеральная служба государственной статистики, http://www.gks.ru/bgd/regl/b15_14p/Main. htm [22.09.2017].

Тархов С.А., 2015, Изменение связности пространства России (на примере авиапассажирского сообщения), Издательство «Ойкумена», Москва - Смоленск.

Шнейдер М.А., 2013, Механизм взаимодействия субъектов рынка пригородных железнодорожных перевозок, Вестник государственного университета морского и речного флота им. адмирала С.О. Макарова, 2(18), 179-185.

Щукин В.В., 2015, Экономическое обоснование системы субсидирования железнодорожных пригородных перевозок. PhD typescript in МГУПС, Москва. 